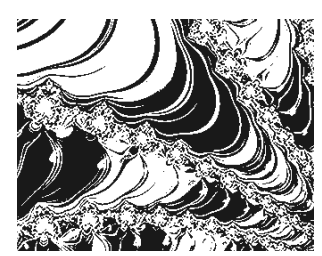

https://doi.org/10.5559/di.30.2.10

\title{
SUSTAINABILITY OF HEALTH AND CARE SYSTEMS: MODELLING THE NURSING EMPLOYMENT DYNAMICS IN AN AGEING POPULATION
}

Barbara GRAH, Vlado DIMOVSKI, Sandra PENGER, Simon COLNAR, David BOGATAJ

School of Economics and Business, University of Ljubljana, Ljubliana, Slovenia

UDK: $331.108 .24(4-6 E U): 614.2+364$

$614.2+364(4-6 E U): 51-7$

Izvorni znanstveni rad

Primljeno: 7. 7. 2020.

Acknowledgment

The research was financed by the Slovenian research agency (ARRS) (project J6-9396 Development of Social Infrastructure and Services for Community Based Long-Term Care and research program P5-0364 The Impact of Corporate Governance, Organizational Learning, and Knowledge Management on Modern Organization).
This study aims to develop an actuarial model to recognise and determine the quality of the healthcare policies, needed to ensure the sustainability of health care systems in terms of a sufficient number of skilled nurses that will cater to the demand of healthcare services from a growing number of older adults in an ageing society and due to pandemics. We have applied the actuarial-mathematical method, which resulted in the proposed multiple decrement model of nurse workforce dynamics. It enables the measurement of the quality of a given national policy system. We built the case of the selected EU economy by applying the proposed model to available statistical data and 15 interviews with nurses, analysed by content analysis. The findings emphasise a lack of nurses in the present as well as a possible lack in the future. It is up to national policies to improve this situation based on the use of the proposed multiple decrement model.

Keywords: health, sustainability, elderly population, ageing, healthcare, nursing profession entrance and exit, multiple decrement model

David Bogatai, School of Economics and Business, University of Ljubljana, Kardeljeva ploščad 17, 1000 Ljubliana, Slovenia E-mail: david.bogataj@ef.uni-li.si 
The sustainability of health and care systems is in question due to the gap between available healthcare human resources and the rising demand from a growing number of older adults and global pandemics. Sustainability of health and care systems is forming a key theoretical framework with which one can deal with the needs of the present population without compromising the ability of future generations (Ziolo et al., 2019). Sustainability is a multifaceted concept that includes environmental, sociocultural, and financial factors (Anåker \& Elf, 2014). A number of studies have linked the sustainability of health and care systems to improvements in people's quality of life (Tur-Porcar et al., 2019). Health sustainability should be part of the national and international strategies of healthcare organisations (Lay, 2007), and it should have properly allocated services in spatial systems (Drobne \& Bogataj, 2014, 2015).

However, today's global nursing shortage is having an opposite impact on health systems, and the global ageing population and pandemics have accentuated the concern regarding this shortage (Leung et al., 2020). Even though the nursing profession plays an important role in ageing societies and research on the sustainability of health and care systems is gaining importance, the modelling of nurse employment dynamics remains poorly researched. The concept of nursing employment dynamics is vague and underexplored and has not been empirically tested or developed. There are no clear considerations of nurses' employment dynamics which measure the quality of the national healthcare policy system.

How one models entrances and exits in the nursing profession is an important theoretical and empirical question. Because of turnovers, one can witness burnouts and identify a lack of organisational strategies (Bonetti et al., 2019). We test and extend this theory by developing a model that enables investigating the factors related to nurse employment dynamics. We draw upon logic, theory, and methodology from the discipline of actuarial science to extend knowledge about the sustainability of health and care systems and the nursing profession in four ways. First, in contrast to the prioritisation of recent studies of the shortage of professional nurses, we document the dynamic perspective of nursing shortage through entrance and exit forecasting. Second, the study highlights various facets of nursing profession dynamics from the demand-and-supply side of health sustainability issues. Third, the proposed multiple decrement model is an objective measuring tool grounded in an actuarial-mathematical method. Fourth, we have validated our study with 15 qualitative field interviews. 


\section{LITERATURE REVIEW}

\section{Sustainability of health and care systems related to availability of nurses: nursing employment - demand side}

The ageing population increases the demand for healthcare services, in which nurses play a crucial part. Nursing is a noble, valued, and honourable profession that focuses on the well being of individuals (Aboshaiqah, 2016). At the contextual level, nurses represent a crucial part of the healthcare workforce (Haddad \& Toney-Butler, 2018). At the practical level, nurses' performances are reliable indicators of the quality of holistic healthcare management (Hassmiller \& Cozine, 2006). Current projections indicate that the supply of nurses cannot meet the demand for professional nursing services. The impact of ageing will present a challenge for almost all member states, as the total age-related expenditures are expected to grow, by $1.7 \%$ p.p., to $26.7 \%$ of gross domestic product between 2016 and 2070.

Bogataj et al. (2015) argue that the ageing of a population entails changes in the field of employment policies, including the nursing workforce. Due to numerous improvements in the medical field, several diseases once considered fatal can now be treated, often requiring long-term healthcare services, which significantly affects the demand side of the nursing workforce. Marć et al. (2019) found that long-term care is an important strategic attribute, requiring a larger number of professionally trained nurses. Scholars have recognised the shortage of human resources in the health profession to be critical (Webber, 2011). It is projected that the shortage of healthcare personnel will rise to 12.9 million by 2035 , which would challenge the sustainability of health and care systems.

\section{Sustainability of health and care systems related to nursing employment - supply side}

The facets relating to the supply-side perspective on nurse employment can be classified into three groups: education, profession specifics, and human resource management (HRM) (Table 1). Aboshaiqah (2016) argued that the supply of an adequate nursing workforce and education of future nurses are core challenges to the sustainability of health and care systems. Insights into data from 12 countries in Europe are critical in considering the shortage of nurses (Marć et al., 2019).

Past research focused on the education of potential nurses, namely on the shortage of academically qualified teaching staff (Nardi \& Gyurko, 2013), as one of the most relevant factors that inform nurses' entrance and exit dynamics (Sawaengdee et al., 2016). The number of age-related exits is reflected in 
DRUŠ. ISTRAŽ. ZAGREB GOD. 30 (2021), BR. 2, STR. 379-400

GRAH, B. ET AL. SUSTAINABILITY OF...

(1) TABLE 1

Facets affecting the supply side of nurse's employment dynamics nursing schools and faculties, which limits the number of nurses who can be trained and who can enter the labour market (Cooley \& De Gagne, 2016). Despite job availabilities in the nursing profession, it continues to struggle. Nurses who possess inadequate knowledge and skills can negatively impact patient healthcare and patient survival chances (Baumann et al., 2001). To ensure future long-term healthcare provision, the nurses' role needs to change. Nurses should have new qualifications, specialise in certain knowledge and skills, and be included in specialised healthcare teams (Marć et al., 2019).

\begin{tabular}{lll}
\hline Facet & Description & Authors \\
\hline Education & Shortages of academically qualified staff & Aiken et al., 2013; Nardi \& \\
& & Gyurko, 2013; Auerbach et al., \\
& & 2015; Sawaengdee et al., 2016; \\
& & Haddad \& Toney-Butler, 2018 \\
Nursing profession & Specifics of nursing profession & Evans \& Frank, 2003; Dietrich \\
& & Leurer et al., 2007; Pillay, 2009; \\
& & Aiken et al., 2013; Sawaengdee \\
& & et al., 2016; Squires et al., 2017; \\
& & Haddad \& Toney-Butler, 2018 \\
Human resource & HRM and working environment & Newman et al., 2001; \\
& management & Aboshaiqah, 2016; Squires et \\
& & al., 2017; Bonetti et al., 2019
\end{tabular}

Scholars outline important specifics of the nursing profession, such as high turnover, the inequitable distribution of the workforce (Sawaengdee et al., 2016) in terms of women's dominance and relevant sociocultural factors (Squires et al., 2017), and the willingness to travel and commute to the workplace (Janež et al., 2018; Drobne \& Bogataj, 2013, 2017). While financial incentives manage to reduce turnover to a degree, a large number of baby-boomer nurses will retire soon, and new nursing graduates will not be able to close that gap due to the limited increase in their numbers (Auerbach et al., 2015). Healthcare systems in developing countries are faced with the challenge of migration of professional nurses not only from rural to urban environments, but internationally as well (Pillay, 2009). Furthermore, the global phenomenon of the migration of healthcare workers from lower-income countries to wealthier ones, provides further insight into the complexity of contemporary issues related to the nursing profession (Kaelin, 2011).

The third facet is HRM and the working environment. The retention of nurses is related to conditions in the work- 
DRUŠ. ISTRAŽ. ZAGREB GOD. 30 (2021), BR. 2, STR. 379-400

GRAH, B. ET AL.: SUSTAINABILITY OF...

\section{METHOD}

ing environment and HRM, which are important factors that influence exits in the nursing profession (Chan et al., 2013). Some graduates quickly acknowledge this is not the profession that they had imagined and drop out. Some who remain may later experience extensive workloads that result in burnout, causing them to leave the profession. Turnover rates in the nursing profession range from $8.8 \%$ to $37.0 \%$ (Nursing Solutions, 2016). Nurses find that their job demands and workloads exceed their capacities and capabilities (Aboshaiqah, 2016). Healthcare management is advised to carefully select nursing middle management, as inappropriate leadership may negatively affect nurses' health and performance (Bonetti et al., 2019).

Furthermore, the costs of nurse training are high, and specific actions should be taken to avoid a high percentage of qualified nurses exiting their profession early (Newman et al., 2001). Nursing shortage and financial impact of failed retention have immediate as well as long-term healthcare effects (Armmer, 2017). Huddleston and Gray (2016) point to the high costs of replacements related to turnover issues and emphasise the importance of a healthy work environment (Tadić Vujčić, 2019). Features of an unhealthy working environment are abusive behaviour, lack of trust, disrespect and poor leadership (Huddleston \& Gray, 2016). Nurses themselves have identified seven different initiatives for effective retention in the nursing profession (Dietrich Leurer et al., 2007): (1) consultation and communication with nurses regarding changes; (2) recognition of their efforts by superiors; (3) adequate staffing; (4) supportive management; (5) flexible work schedules and work-life balance; (6) supporting new nurses with wisdom and knowledge; (7) professional development.

\section{Multiple decrement model of nursing profession dynamics}

To investigate the dynamics of the nursing profession, we propose the multiple decrement model (Bogataj et al., 2015). For the successful forecasting of different states of nurses, we develop the model to forecast the entrances and exits in the nursing profession in each age cohort and derive the probabilities of transition at various ages at the regional and national levels, based on a demographic multiple decrement model. The model will enable long-term projections of available nurses in different states of productivity and facilitate an understanding of the patterns regarding entrances and exits in the nursing workforce, contextualising how different policies influence the dynamics. The nurses can belong to various states, 
DRUŠ. ISTRAŽ. ZAGREB GOD. 30 (2021), BR. 2, STR. 379-400

GRAH, B. ET AL.: SUSTAINABILITY OF...

- FIGURE 1

Transitions to and from employment for nurses from nursing student to nurses who are changing professions or retiring or who die (Figure 1). In multiple decrement models we have $\mathrm{m}+1$ different states for nurses.

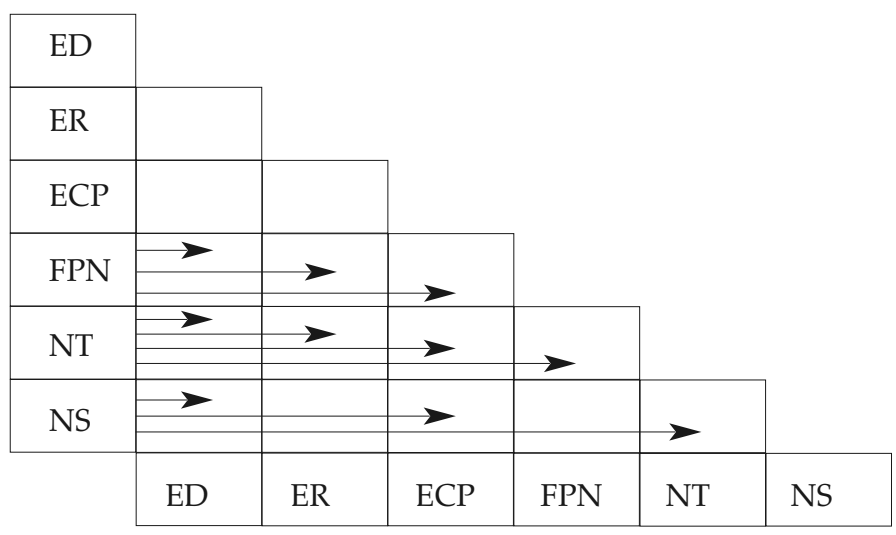

Legend: NS - nursing student $(i=0)$; NT - nurse trainee $(i, j=1)$; FPN - fully productive nurse $(i, j=2)$; ECP - exit by changed profession $(i, j=3)$; ER - exit by retirement $(i, j=4)$; ED - exit by death or other kind of losing them forever $(j=5)$; relevant transitions for policymakers are marked with arrows. Emigrated are included in $\mathrm{j}=5$.

We denote the initial state (number of nursing students) as state 0 , and transition, which models a nurse in the state of type $\mathrm{i}$ by the line of the graph from this node to the state (node) $\mathrm{j}, \mathrm{j}=1,2, \ldots \mathrm{m}$. The model describes the probabilities of transition from state 0 to state $j \in W$ (where $W$ is the set of different categories of nurse productivity). All paths to $\mathrm{j}$ determine the dynamics of HRM. In a multiple-decrement setup, transitions between any two states (from $i$ to $j, i>j$ ) are not possible (the graph is directed). A nurse aged $x$ is denoted by (x). The number of nurses in age $x$ is denoted by $S_{x}$. Thus, $x+T_{i}(x)$ will be the age when the nurse exits the current state $i$ and enters a new state $j, j \in W$. The future work period in the category of type $\mathrm{i}, \mathrm{T}_{\mathrm{i}}(\mathrm{x})$, is a random variable with a probability distribution function:

$$
\mathrm{G}_{\mathrm{i}}(\tau)=\operatorname{Pr}\left(\mathrm{T}_{\mathrm{i}} \leq \tau\right), \tau \geq 0
$$

$\mathrm{G}_{\mathrm{i}}(\tau)$ represents the probability of the nurse exiting the profession within $\tau$ years, for any fixed $\tau$. We assume that in $\mathrm{G}_{i}(\tau)$, the probability distribution of $T_{i}$, is known, continuous, and has a probability density $g_{i}(\tau)=G_{i}^{\prime}(\tau)$. The data for $G_{i}(\tau)$ should be obtainable from national statistics. Thus, one can describe the following:

$$
\mathrm{g}_{\mathrm{i}}(\tau) \mathrm{d} \tau=\operatorname{Pr}\left(\tau<\mathrm{T}_{\mathrm{i}}<\tau+\mathrm{d} \tau, \mathrm{i} \in \mathrm{W}\right)
$$

where (2) describes the probability of the nurse transferring from the state of productivity $i$, in the infinitesimal time 
DRUŠ. ISTRAŽ. ZAGREB GOD. 30 (2021), BR. 2, STR. $379-400$

GRAH, B. ET AL.: SUSTAINABILITY OF... interval, from $\tau$ to $\tau+\mathrm{d} \tau$. The probability that a nurse who is $x$ years old and in a state of productivity i transferring into a state of productivity $j$ within $\tau$ years is denoted by ${ }_{\tau} q_{x}(i, j)$. We have the relationships for probability of transitions from $i$, to $\mathrm{j}$ as the states in Figure 1:

$$
{ }_{\tau} \mathrm{q}_{\mathrm{x}}(\mathrm{i}, \mathrm{j})=\mathrm{G}(\mathrm{i}, \mathrm{j}: \tau) ; \tau=1 \rightarrow{ }_{\tau} \mathrm{q}_{\mathrm{x}}(\mathrm{i}, \mathrm{j})=q_{x t}^{(i, j)}
$$

where $q$ can change by years (by t). Similarly, one can write the probability of stay in the same status:

$$
{ }_{\tau} \mathrm{p}_{\mathrm{x}}(\mathrm{i})=1-\sum_{j=i+1}^{m} \mathrm{G}(\mathrm{i}, \mathrm{j}: \tau) ; \tau=1 \rightarrow{ }_{\tau} \mathrm{p}_{\mathrm{x}}(\mathrm{i})=p_{x, t}^{(i)},
$$

where $\mathrm{p}$ can change by years $(\mathrm{t})$. Here $p_{x, t}^{(i)}$ denotes the probability that an $x$-year-old nurse in year $t$ will remain in their current state $\mathrm{i}$ for at least 1 year.

The graph starts at an initial state $\mathrm{i}=$ NS (nursing student). Based on national statistics, we can observe all possible paths and calculate probabilities (as relative frequencies obtained from statistics) of their realisation from NS through some of the identified child nodes $j \in W$. These probabilities are subjects of the matrix $\mathbf{P}_{x, t}$ in equation (5). The structure of nursing students and nurses at age $x$ in year $t$ is described with vector $S_{x, t}$. Forecasting the distribution of nurses at age $x$ in the year $t+1$, denoted with $S_{x+1, t+1}$ is the product of vector $S_{x, t}$ and the transition matrix $\mathbf{P}_{x, t}$. To this product we add the vector of immigration $\mathbf{M}_{x, t}$. These states should be summarised through nurses of all ages to $S_{t}=\Sigma_{x} S_{x, t}$ according to their states of productivity:

$$
\begin{aligned}
& \mathbf{S}_{x+1, t+1}^{\mathbf{z}}=\mathbf{S}_{x, t} \cdot \mathbf{P}_{x, t}= \\
& =\left[S_{x, t}^{(0)} S_{x, t}^{(1)} S_{x, t}^{(2)} S_{x, t}^{(3)} S_{x, t}^{(4)} S_{x, t}^{(5)}\right]\left[\begin{array}{lllllll}
p_{x, t}^{(0)} & q_{x, t}^{(0,1)} & q_{x, t}^{(0,2)} & q_{x, t}^{(0,3)} & q_{x, t}^{(0,4)} & q_{x, t}^{(0,5)} \\
0 & p_{x, t}^{(1)} & q_{x, t}^{(1,2)} & q_{x, t}^{(1,3)} & q_{x, t}^{(1,4)} & q_{x, t}^{(1,5)} \\
0 & 0 & p_{x, t}^{(2)} & q_{x, t}^{(2,3)} & q_{x, t}^{(2,4)} q_{x, t}^{(2,5)} \\
0 & 0 & 0 & p_{x, t}^{(3)} & q_{x, t}^{(3,4)} q_{x, t}^{(3,5)} \\
0 & 0 & 0 & 0 & p_{x, t}^{(4)} & q_{x, t}^{(4,5)} \\
0 & 0 & 0 & 0 & 0 & 1
\end{array}\right]= \\
& =\left[S_{x+1, t+1}^{z(0)} S_{x+1, t+1}^{z(1)} S_{x+1, t+1}^{z(2)} S_{x+1, t+1}^{z(3)} S_{x+1, t+1}^{z(4)} S_{x+1, t+1}^{z(5)}\right] \\
& {\left[S_{x, t+1}^{(0)} S_{x, t+1}^{(1)} S_{x, t+1}^{(2)} S_{x, t+1}^{(3)} S_{x, t+1}^{(4)} S_{x, t+1}^{(5)}\right]=\mathbf{S}_{x+1, t+1}^{\mathbf{z}}+\mathbf{M}_{x, t}}
\end{aligned}
$$

Where with the last line of $\mathbf{P}$ we summarise those who died or are lost for the system. $\mathbf{M}_{x, t}$ is vector of immigrations, while emigrations are already included in the 6th column of the transition matrix. 


\section{Research results based on the multiple decrement model}

TABLE 2

Number of students enrolled

O TABLE 3

Employees in health and social care in 2017
A registered nurse is perceived as one with a graduate degree, while in Slovenia, a nurse is perceived as possessing a graduate degree and a secondary school diploma. In the study year 2016-17, 8\% of total high-school students in Slovenia enrolled in the Secondary School of Nursing (Table 2) (Ministry of Education, Science, and Sport, n.a.). The number of employees in healthcare in Slovenia as of 2017 was 42.994 (Slovenian Statistical office, n.a.), of which 21.141 were nurses (Table 3) (National Institute for Public Health, n.a.).

\begin{tabular}{lcc}
\hline & Veterinary technician & Healthcare \\
\hline $2012 / 13$ & 184 & 1081 \\
$2013 / 14$ & 189 & 1127 \\
$2014 / 15$ & 185 & 1045 \\
$2015 / 16$ & 180 & 1013 \\
$2016 / 17$ & 179 & 1025 \\
\hline
\end{tabular}

Source: Ministry of Education, Science and Sport, n.a.

\begin{tabular}{lrrr}
\hline Ages & $\begin{array}{c}\text { Healthcare and } \\
\text { social care }\end{array}$ & Healthcare & Social care \\
\hline Total & 62367 & 42994 & 19373 \\
$15-19$ & 202 & 95 & 107 \\
$20-24$ & 2527 & 1590 & 937 \\
$25-29$ & 6739 & 5143 & 1596 \\
$30-34$ & 8371 & 6214 & 2157 \\
$35-39$ & 8304 & 5861 & 2443 \\
$40-44$ & 8206 & 5380 & 2826 \\
$45-49$ & 8029 & 4979 & 3050 \\
$50-54$ & 9714 & 6267 & 3447 \\
$55-59$ & 7643 & 5345 & 2298 \\
$60-64$ & 2075 & 1583 & 492 \\
$65+$ & 557 & 537 & 20 \\
\hline
\end{tabular}

Source: Slovenian Statistical Office, n.a.

Let us assume that the number of new nurses who graduated in 2017 was equal to the number enrolled in the school year 2016/2017 (1025). We also assume that these graduated nurses are 18 years old in 2017 and all enrolled for the required training in the same year. Immigrations are not included in this case study. Therefore, the initial vector (January 1, 2017) is:

$$
\begin{aligned}
\mathbf{S}_{18,2017} & =\left[S_{18, t}^{(0)} S_{18, t}^{(1)} S_{18, t}^{(2)} S_{18, t}^{(3)} S_{18, t}^{(4)} S_{18, t}^{(5)}\right]_{2017}= \\
& =\left[\begin{array}{llllll}
1025 & 0 & 0 & 0 & 0 & 0
\end{array}\right]
\end{aligned}
$$


DRUŠ. ISTRAŽ. ZAGREB GOD. 30 (2021), BR. 2, STR. $379-400$

GRAH, B. ET AL.: SUSTAINABILITY OF..
The transition matrix was constructed based on demographic data and employment tables for different occupation groups for the year 2017, collected at the national level by the Slovenian Statistical Office and from registration of employment from M1 and M2 forms by The Health Insurance Institute of Slovenia. We assume that the policies influencing the transition matrix will remain constant in the following years. Therefore, the constant yearly transition matrix would be as follows:

$$
\begin{aligned}
& \mathbf{P}_{x, 2017}=\mathbf{P}_{x, t}=\mathbf{p}= \\
& =\left[\begin{array}{llllll}
0 & 0,999 & 0 & 0 & 0 & 0,001 \\
0 & 0 & 0,999 & 0 & 0 & 0,001 \\
0 & 0 & 0,964 & 0,030 & 0,005 & 0,001 \\
0 & 0 & 0 & 0,989 & 0,010 & 0,001 \\
0 & 0 & 0 & 0 & 0,999 & 0,001 \\
0 & 0 & 0 & 0 & 0 & 1
\end{array}\right]
\end{aligned}
$$

In this case, we can write for them the first transition, which is available in the statistics of January 1st, 2018:

$$
\begin{aligned}
\mathbf{S}_{19,2018} & =\left[\begin{array}{llrllll}
1025 & 0 & 0 & 0 & 0 & 0
\end{array}\right] \cdot \\
& \cdot \mathbf{P}=\left[\begin{array}{llllll}
0 & 1024 & 0 & 0 & 0 & 1
\end{array}\right]
\end{aligned}
$$

and for the second year, when they enter employment status:

$$
\begin{aligned}
\mathbf{S}_{20,2019} & =\left[\begin{array}{llllll}
0 & 1024 & 0 & 0 & 0 & 1
\end{array}\right] \cdot \\
& \cdot \mathbf{P}=\left[\begin{array}{llllll}
0 & 0 & 1023 & 0 & 0 & 2
\end{array}\right]
\end{aligned}
$$

What would be their allocation after $\tau$ years? If the demographic figures, salaries and other benefits do not change, if the matrix does not change, we can write:

$$
\mathbf{S}_{18+\tau, 2017+\tau}=\mathbf{S}_{18,2017} \cdot \mathbf{P}^{\tau}
$$

For example, after 18 years, if there are no immigrations, the structure of vector $S$ would be:

$$
\mathbf{S}_{36,2035}=\mathbf{S}_{18,2017} \cdot \mathbf{P}^{18}=\left[\begin{array}{llllll}
0 & 0 & 569 & 346 & 92 & 18
\end{array}\right]
$$

According to the transition matrix of nurses, their number in employment will decrease. Therefore, in 16 years, we may lose 454 nurses. Upon summarising the effects of our nurse-employment policy over all cohorts, we can see that this loss is enormous.

Understanding workforce entrances and exits in the nursing profession is essential for providing the required nursing services for the ageing population. The quality of HRM contributes to young people choosing the nursing profession and 
DRUŠ. ISTRAŽ. ZAGREB GOD. 30 (2021), BR. 2, STR. 379-400

GRAH, B. ET AL.: SUSTAINABILITY OF...

$\rightarrow$ TABLE 4

Nurses ageing from

18 years in 2017 to 64 years in 2063 (no immigration scenario) encourages existing nurses to remain in their profession. Table 4 presents the forecast regarding availability of nurses aged 18 (in 2017) up to the studied year 2063, when they will be 64 years old.

\begin{tabular}{|c|c|c|c|c|c|c|c|}
\hline Year & Age & NS & NT & FPN & ECP & ER & ED \\
\hline 2017 & 18 & 1025 & 0 & 0 & 0 & 0 & 0 \\
\hline 2018 & 19 & 0 & 1024 & 0 & 0 & 0 & 1 \\
\hline 2019 & 20 & 0 & 0 & 1023 & 0 & 0 & 2 \\
\hline 2020 & 21 & 0 & 0 & 986 & 31 & 5 & 3 \\
\hline 2021 & 22 & 0 & 0 & 951 & 60 & 10 & 4 \\
\hline 2022 & 23 & 0 & 0 & 916 & 88 & 16 & 5 \\
\hline 2023 & 24 & 0 & 0 & 883 & 114 & 21 & 6 \\
\hline 2024 & 25 & 0 & 0 & 852 & 140 & 27 & 7 \\
\hline 2025 & 26 & 0 & 0 & 821 & 164 & 32 & 8 \\
\hline 2026 & 27 & 0 & 0 & 791 & 186 & 38 & 9 \\
\hline 2027 & 28 & 0 & 0 & 763 & 208 & 44 & 10 \\
\hline 2028 & 29 & 0 & 0 & 735 & 229 & 50 & 11 \\
\hline 2029 & 30 & 0 & 0 & 709 & 248 & 56 & 12 \\
\hline 2030 & 31 & 0 & 0 & 683 & 267 & 62 & 13 \\
\hline 2031 & 32 & 0 & 0 & 659 & 284 & 68 & 14 \\
\hline 2032 & 33 & 0 & 0 & 635 & 301 & 74 & 15 \\
\hline 2033 & 34 & 0 & 0 & 612 & 317 & 80 & 16 \\
\hline 2034 & 35 & 0 & 0 & 590 & 332 & 86 & 17 \\
\hline 2035 & 36 & 0 & 0 & 569 & 346 & 92 & 18 \\
\hline 2036 & 37 & 0 & 0 & 548 & 359 & 98 & 19 \\
\hline 2037 & 38 & 0 & 0 & 529 & 371 & 105 & 20 \\
\hline 2038 & 39 & 0 & 0 & 510 & 383 & 111 & 21 \\
\hline 2039 & 40 & 0 & 0 & 491 & 394 & 117 & 22 \\
\hline 2040 & 41 & 0 & 0 & 474 & 405 & 123 & 23 \\
\hline 2041 & 42 & 0 & 0 & 457 & 414 & 130 & 24 \\
\hline 2042 & 43 & 0 & 0 & 440 & 424 & 136 & 25 \\
\hline 2043 & 44 & 0 & 0 & 424 & 432 & 142 & 26 \\
\hline 2044 & 45 & 0 & 0 & 409 & 440 & 149 & 27 \\
\hline 2045 & 46 & 0 & 0 & 394 & 448 & 155 & 28 \\
\hline 2046 & 47 & 0 & 0 & 380 & 454 & 161 & 29 \\
\hline 2047 & 48 & 0 & 0 & 366 & 461 & 167 & 30 \\
\hline 2048 & 49 & 0 & 0 & 353 & 467 & 174 & 31 \\
\hline 2049 & 50 & 0 & 0 & 341 & 472 & 180 & 32 \\
\hline 2050 & 51 & 0 & 0 & 328 & 477 & 186 & 33 \\
\hline 2051 & 52 & 0 & 0 & 316 & 482 & 192 & 34 \\
\hline 2052 & 53 & 0 & 0 & 305 & 486 & 199 & 35 \\
\hline 2053 & 54 & 0 & 0 & 294 & 490 & 205 & 36 \\
\hline 2054 & 55 & 0 & 0 & 283 & 493 & 211 & 37 \\
\hline 2055 & 56 & 0 & 0 & 273 & 496 & 217 & 38 \\
\hline 2056 & 57 & 0 & 0 & 263 & 499 & 223 & 39 \\
\hline 2057 & 58 & 0 & 0 & 254 & 502 & 229 & 40 \\
\hline 2058 & 59 & 0 & 0 & 245 & 504 & 235 & 41 \\
\hline 2059 & 60 & 0 & 0 & 236 & 505 & 241 & 42 \\
\hline 2060 & 61 & 0 & 0 & 228 & 507 & 247 & 43 \\
\hline 2061 & 62 & 0 & 0 & 219 & 508 & 253 & 44 \\
\hline 2062 & 63 & 0 & 0 & 211 & 509 & 259 & 45 \\
\hline 2063 & 64 & 0 & 0 & 204 & 510 & 265 & 46 \\
\hline
\end{tabular}




\section{Understanding the reasons for the shrinking number of employed nurses}

To understand the nursing situation in Slovenia, we performed 15 online interviews in April/May 2020. We designed the research instrument for qualitative research, consisting of control variables (i.e. gender, age), and five open-ended questions. We performed in-depth interviews, as they enable researchers to further explore their insight on a particular topic (Boyce \& Neale, 2006). We were able to obtain additional information about individuals' thoughts and to enrich the studied phenomena (Roulston, 2010). Moreover, we were able to pose questions that reflected the researchers' hypotheses about the studied phenomena in a way that combined previous research on the studied topics as well as our assumptions and knowledge (Deterding \& Waters, 2018). Due to the ongoing Covid-19 pandemic, and related work pressure for nurses as well as governmental restrictions, the questionnaire was in online mode. To collect data, we contacted the internal informer working in the selected public medical hospital, who took care of the dissemination of the online questionnaires. Anonymity was ensured by the online questionnaire form. Altogether, we collected 15 valid responses from nurses. To analyse the data, content analysis was conducted. To ensure the reliability of the study procedure, in the first step, two researchers independently analysed the collected data and, in the second step, discussed findings and selected the most representative proof quotations. To enhance the verification of the qualitative assessment, we triangulated primary data through rich data context for understanding and interpreting the words of the respondents on the nursing employment dynamics phenomena. We also employed methodological triangulation conducted through a combination of developed multiple decrement model and the qualitative part of the study (Yin, 2011).

Out of the 15 respondents, 14 were females and the respondents' average working age was low, all of them working in health and care services and having adequate education. The field study exposed ideas that had the potential to shape our research field, and our notion that, based on the growing number of older adults in an ageing society as well as global pandemics, the wellbeing of a given population cannot be achieved without a sufficient number of well-educated and skilled nurses. Understanding the patterns of the nurse workforce dynamics is important for policymakers in elderly societies, for which appropriate tools need to be developed, to enable the appropriate decisions. Table 5 presents the coding and systematic overview of the qualitative study. 


\begin{tabular}{|c|c|c|c|}
\hline & & $N$ & $\%$ \\
\hline $\begin{array}{l}\text { Do enough young people } \\
\text { choose the nurses profession }\end{array}$ & $\begin{array}{l}\text { Yes } \\
\text { No } \\
\text { Not specified }\end{array}$ & $\begin{array}{l}7 \\
6 \\
2\end{array}$ & $\begin{array}{l}46.7 \\
40.0 \\
13.3\end{array}$ \\
\hline Advantages of nursing profession & $\begin{array}{l}\text { Helping people } \\
\text { Availability of job opportunities } \\
\text { None }\end{array}$ & $\begin{array}{r}10 \\
3 \\
2\end{array}$ & $\begin{array}{l}66.7 \\
20.0 \\
13.3\end{array}$ \\
\hline $\begin{array}{l}\text { Problems and challenges } \\
\text { of nursing profession }\end{array}$ & $\begin{array}{l}\text { Staffing } \\
\text { Working conditions } \\
\text { Payment } \\
\text { Relations } \\
\text { Respectfulness } \\
\text { No problems } \\
\text { Not specified }\end{array}$ & $\begin{array}{r}4 \\
11 \\
3 \\
1 \\
6 \\
1 \\
2\end{array}$ & $\begin{array}{r}26.7 \\
73.3 \\
20.0 \\
6.7 \\
40.0 \\
6.7 \\
13.3\end{array}$ \\
\hline Future of nursing profession & $\begin{array}{l}\text { Positive, key } \\
\text { Negative } \\
\text { Not specified } \\
\text { No answer }\end{array}$ & $\begin{array}{l}8 \\
2 \\
4 \\
1\end{array}$ & $\begin{array}{r}53.3 \\
13.3 \\
26.7 \\
6.7\end{array}$ \\
\hline Nursing profession after Covid-19 & $\begin{array}{l}\text { More responsibilities } \\
\text { More respect } \\
\text { No change } \\
\text { Not specified } \\
\text { No answer }\end{array}$ & $\begin{array}{l}2 \\
2 \\
8 \\
1 \\
2\end{array}$ & $\begin{array}{r}13.3 \\
13.3 \\
53.3 \\
6.7 \\
13.3\end{array}$ \\
\hline
\end{tabular}

i) TABLE 5

Systematic presentation of qualitative results
The first question focused on nurses' opinions as to whether enough young people choose the nursing profession. There were two balanced groups of answers, the first one claiming that there are enough young people who chose the nursing profession:

R4: 'So far enough, mostly because it's easier to get a job. Few choose a profession as a mission';

R13: 'I think a lot of young people are opting for the nursing profession. Because the profession is reputable and offers help to people'.

Meanwhile, the other group opined that the number of youths opting for nursing is not sufficient:

R3: 'No. Burnout. Bad relationships';

R9: 'No, underpaid work for never being home. Too much responsibility and pressure for this pay, underappreciated profession, deteriorating working conditions, fewer challenges, not considered when making decisions, too much mobbing in the workplace.'

The respondents also questioned the motive for choosing the nursing profession: 
DRUŠ. ISTRAŽ. ZAGREB GOD. 30 (2021), BR. 2, STR. $379-400$

GRAH, B. ET AL. SUSTAINABILITY OF...
R11: 'The motive for choosing the profession is wrong, especially for high school. Low enrolment criteria encourage enrolment of people who have failed at school, have poor self-esteem, and are later dissatisfied with their profession. Sufficient persons opt for a graduate nurse; in most cases the number of accepted students is limited. The professional image of a nurse in Slovenia is distorted, in most cases, people think that she is a doctor's assistant...'.

We asked respondents about the advantages of the nursing profession. Several mentioned "helping people":

R1: 'The advantage is that you know how to help people. A wonderful profession, but not appreciated enough.';

R4: 'Advantages??? All that is left for us is that at least some of us feel satisfied to do something good for our fellow men.'

Several respondents mentioned no such advantages exist:

R3: 'There are none.';

R9: 'There are none, it is better to be a hairdresser, only heart and sacrifice still keeps us in the profession. The brave and smart ones change profession and have the opportunity to make a career.'

According to the respondents, the biggest problems they face are related to HRM and the working environment:

R2: 'Inhumane schedule, poorly paid work, disrespect.';

R9: 'It is difficult to make a career, there is no possibility of decision-making, always among the forgotten and unpaid ones, it is becoming unknown who drinks and who pays [phrase], more and more meaningless directives and pressures, more and more savings on quality, more and more hidden mistakes, less or almost no high-quality education and knowledge transfer.'

If they could, they would implement changes:

R10: 'Less paperwork, more time for patients.';

R11:'More insurance companies... The work of nurses is also poorly valued because the consultants at the insurance company are mostly doctors. The nurse should be responsible for her work, her role in the team should be clearly visible.'

There are also exceptions, as

R14 claims: 'I do my job with pleasure, and I have no problems related to that'. 
DRUŠ. ISTRAŽ. ZAGREB GOD. 30 (2021), BR. 2, STR. 379-400

GRAH, B. ET AL.: SUSTAINABILITY OF...

\section{DISCUSSION}

On the future of the nursing profession with regard to pandemics and population ageing, the respondents said nurses have a key role:

R1: 'During this pandemic, it turned out that it is not possible without nurses. I wish the profession were more respected.';

R8: 'It's a very demanding profession.'.

R13 highlighted the dangers of the current situation continuing: 'Burnout, staff shortage, people [nurse] won't want to work for low pay',

R14 assumed that more nurses would be needed: 'One of the solutions is staff reinforcement.'

On changes anticipated after the pandemic, opinions were divided. More than half stated that nothing would change:

R4: 'The work will continue in the same way, but if we will learn something from the quarantine period, there is a ray of hope that things could get better.';

R11: 'It will not change; care is the basic mission of nurses. ... The changes will be visible in the organisation and treatment of the patients, but not in the specific nursing services.'

On the other hand, some anticipated negative changes, while others expected positive ones:

R1: 'It has changed in a way that we have to carry a greater burden, especially in terms of disinfection and protection against infection';

R6: 'Maybe yes. Nurses will be more respected'.

\section{Theoretical contributions}

Nurses make major contributions to the health and wellbeing of the older population. We have developed the model of nursing profession dynamics that projects a long-term shortage of nurses. Nurses can positively contribute to the sustainability of health and care systems by improving human health within the physical, economic, and social environments. The research findings have important theoretical and practical implications.

First, our study contributes to related research on the sustainability of health and care systems by examining the global shortage of nursing staff and offering evidence to reconcile the partial results of prior research. Our study allowed us to identify 15 emergent issues on the supply side and six on the demand side of the sustainability of health and care systems. Nurses themselves reported seven initiatives for effective retention in the nursing profession: (1) consultation and com- 
(1) TABLE 6

Pillars of sustainability

of health and care systems affected by nursing dynamics in an ageing society through the views of the authors studied in the previous chapters and our qualitative study munication with nurses regarding changes; (2) recognition of their efforts by superiors; (3) adequate staffing; (4) supportive management; (5) flexible work schedules and work-life balance; (6) supporting new nurses with wisdom and knowledge; and (7) professional development. The three main pillars of sustainability of health and care systems affected by nursing dynamics in an ageing society through the views of the authors studied in the previous chapters and our qualitative study are given in Table 6.
Supply side - Providers' perspective

$\begin{array}{ll}\text { Environmental } & \begin{array}{l}\text { Need to adapt to build environmental } \\ \text { pillar }\end{array} \\ & \text { (Drobne \& Bogataj, 2017). } \\ & \text { Lack of promotion of green initiatives } \\ & \text { (Anåker \& Elf, 2014). } \\ & \text { Healthy work environment } \\ & \text { (Zydziunaite et al., 2015). } \\ \text { Social pillar } & \text { Ageing of nurses, migration } \\ & \text { (Janež et al., 2018). } \\ & \text { Organisational system reconfiguration, } \\ & \text { patient-centred environment } \\ & \text { (Kieft et al., 2014). } \\ & \text { Adjusted competences in nursing } \\ & \text { profession (Kuokkanen et al., 2016). } \\ & \text { The need for healthcare system } \\ & \text { reorganisation (Dyrbye \& } \\ & \text { Shanafelt, 2011). } \\ & \text { E-health and other technological } \\ & \text { solutions (Kieft et al., 2014). } \\ & \text { Collaborative working relationships } \\ & \text { (Kieft et al., 2014). }\end{array}$

Economic pillar Long-term balance of health ecosystem and financial sustainability

(Manton et al., 2006).

Higher costs of patient healthcare and tendency to increase nurses' salaries

(Needleman et al., 2006).

Lower profits (Govindarajan \&

Ramamurti, 2013).

Control over nursing practice

(Kieft et al., 2014).

Cost-effective policy and transparency goals (Kieft et al., 2014).
Demand side - Patients' perspective

Environmental health issues

(Anåker \& Elf, 2014).

Healthy work environment and positive attitude

towards patients (Ritter, 2011).

Lack of specialised healthcare services (Krug \& Cieza, 2019). Patient safety, patient-centred culture (Kieft et al., 2014).

Less choice of where to go, quality of healthcare services (Kennedy, 2017).

Fewer providers available, higher prices of healthcare services (Drobne \& Bogataj, 2014, 2015, 2017).

Second, we integrated the multiple decrement model of nurses' workforce dynamics to deepen our understanding of patterns, which can inform specific policymakers in ageing societies, and address concerns about nursing shortages being a repetitive phenomenon (Buchan, 2002). This is in line with the 
DRUŠ. ISTRAŽ. ZAGREB GOD. 30 (2021), BR. 2, STR. 379-400

GRAH, B. ET AL.: SUSTAINABILITY OF... previous research finding (Kieft et al., 2014) that nurses consider the following factors for improving patients' involvement in the quality of nursing: clinically competent nurses, collaborative working relationships, autonomous nursing practice, adequate staffing, control over nursing practice, managerial support, and a patient-centred culture. As nurses feel pressured to increase productivity and report a high administrative workload, the risk of burnout (Dyrbye \& Shanafelt, 2011) will increase.

Further, our study contributes to the existing nursing literature by incorporating the impact of the supply and demand sides of the sustainability of health and care systems on the future of nurse dynamics. Rather than merely allocating partial causes to the global nursing shortage, the incorporation of dynamic forecasting of future nurse workforce needs, distributed in accordance with the environmental, social, and economic pillars of the sustainability of health and care systems, plays an active role in shaping those factors. The future of the nursing profession must support attracting new graduates and retaining skilled nursing staff. This is in line with previous research which recognises that future nursing shortages should not be tackled solely by increasing the supply of new graduates (Barnett et al., 2010).

\section{Practical implications}

National policymakers in ageing societies should acknowledge that the challenges related to long-term healthcare have become global issues. To contribute to the sustainability of health and care systems, one must improve the transition of nurses from their educational institutions to workplaces, retain nurses in their jobs, and improve the manner of their deployment (Health Workforce Australia, 2014). Our research allows the measurement of the quality of national policy systems related to the nursing profession. It shows how an optimum increase in their working period and influence of investment in promotional and motivational solutions and education can increase their availability. Results suggest that national economies should bestow adequate consideration when forecasting recommended changes on the supply side to meet the demand.

We propose that national policies should develop and introduce the best strategies and practices based on education, motivation, and profession promotion. This has important implications for healthcare leadership; in addition to aiding the development of sustainable organisational strategies and procedures in the nursing profession, hospital leadership should endeavour to create healthy work environments. Our recommendation is in line with the state-of-the-art research of Marć et al. (2019). 


\section{Limitations and future research directions}

The first limitation of this research is that our national-section data prevented our arriving at a conclusive forecast of further needs related to the global nursing shortage, which should be an avenue for further research. The second limitation is the usage of self-categorised data regarding the probability of nurses transitioning from one state to another, which could have led us to either underestimate or overestimate the future need for nurses. Third, we should consider the contextual role of national economies, namely the existing national educational system and relevant national policies. Fourth, the ongoing Covid-19 pandemic made it impossible for us to collect the data in person on the one hand, and on the other, it increased the workload of nurses, leaving them with less time to participate in this study. Future research should be focused on other stakeholders of the healthcare system, as, for example, healthcare services providers, doctors, as well as social workers, patients, and others. Future research should also look into why national economies and policies are not yet prepared to tackle the healthcare needs of rapidly ageing societies.

\section{CONCLUSIONS}

Population ageing increases the number of older adults who need healthcare services, and a shortage of nurses poses serious concerns relating to the sustainability of health and care systems. The sustainability of a welfare state will be challenged if there are not enough nurses to care for the increasing number of older adults. A large number of academic papers highlight the problem of a global nurse shortage, but no paper in the Web of Science has presented a model that enables policymakers to understand the patterns that mark nursing profession dynamics, the projections of which depend on policies.

Therefore, in this article we have developed the model of actuarial mathematics by which we can assume the dynamics of number of nurses, as well as show how we can use various government policies to influence the change in the transition matrix and thus increase the number of available nurses. Not only wages, but the list of environmental, social and economic pillars, as given in Table 6, influence young people to choose this profession and to stay in it. But according to our interviews, also the problems and challenges of the nursing profession, like working conditions and respectfulness, influence the transition matrix. We also modelled how the policy of attracting workers from abroad (influencing vector $\mathbf{M}$ ) can affect a greater number of much-needed nurses.

To support policymakers in accepting decisions regarding incentives for entering the education process and supporting the motivation of nurses, public databases of EU member states 
DRUŠ. ISTRAŽ. ZAGREB GOD. 30 (2021), BR. 2, STR. $379-400$

GRAH, B. ET AL.: SUSTAINABILITY OF...

\section{REFERENCES}

and Eurostat need to be developed to measure the efficiency of different policies on the availability of nurses.

The results of this paper are highly relevant and have important potential impacts: (1) the existing supply of nurses is not sufficient in the long term, (2) investments in HRM are not sufficiently high to provide enough qualified nurses, and (3) the developed model allows a better understanding of patterns relevant to nurse entrances and exits and can be used by different institutions. The results of appropriate HRM in healthcare should facilitate important contributions in terms of ensuring social and healthcare services in ageing societies (European Commission, 2015).

Aboshaiqah, A. (2016). Strategies to address the nursing shortage in Saudi Arabia. International Nursing Review, 63(3), 499-506. https://doi. org/10.1111/inr.12271

Aiken, L. H., Sloane, D. M., Bruyneel, L., Van den Heede, K., Sermeus, W., \& Rn4cast Consortium (2013). Nurses' reports of working conditions and hospital quality of care in 12 countries in Europe. International Journal of Nursing Studies, 50(2), 143-153. https://doi.org/10. 1016/j.ijnurstu.2012.11.009

Anåker, A., \& Elf, M. (2014). Sustainability in nursing: A concept analysis. Scandinavian Journal of Caring Sciences, 28(2), 381-389. https://doi. org $/ 10.1111 /$ scs.12121

Armmer, F. (2017). An inductive discussion of the interrelationships between nursing shortage, horizontal violence, generational diversity, and healthy work environments. Administrative Sciences, 7(4), 34. https://doi.org/10.3390/admsci7040034

Auerbach, D. I., Buerhaus, P. I., \& Staiger, D. O. (2015). Will the RN workforce weather the retirement of the baby boomers? Medical Care, 53(10), 850-856. https://doi.org/10.1097/MLR.0000000000000415

Barnett, T., Namasivayam, P., \& Narudin, D. A. A. (2010). A critical review of the nursing shortage in Malaysia. International Nursing Review, 57(1), 32-39. https://doi.org/10.1111/j.1466-7657.2009.00784.x

Baumann, A., Giovannetti, P., O'Brien-Pallas, L., Mallette, C., Deber, R., Blythe, J., Hibberd, J., \& DiCenso, A. (2001). Healthcare restructuring: The impact of job change. Canadian Journal of Nursing Leadership, 14(1), 14-20. https://doi.org/10.12927/cjnl.2001.16306

Bogataj, D., McDonnell, D. R., \& Bogataj, M. (2015). Reverse mortgage schemes financing urban dynamics using the multiple decrement approach. In J. A. Londoño, J. Garrido, \& D. Hernández-Hernández (Eds.), Actuarial sciences and quantitative finance (pp. 27-47). Springer. https://doi.org/10.1007/978-3-319-18239-1_3

Bonetti, L., Tolotti, A., Valcarenghi, D., Pedrazzani, C., Barello, S., Ghizzardi, G. Graffigna, G., Sari, D., \& Bianchi, M. (2019). Burnout precursors in oncology nurses: A preliminary cross-sectional study with a systemic organizational analysis. Sustainability, 11(5), 1246. https://doi. org/10.3390/su11051246 
DRUŠ. ISTRAŽ. ZAGREB GOD. 30 (2021), BR. 2, STR. 379-400

GRAH, B. ET AL.: SUSTAINABILITY OF...
Boyce, C. \& Neale, P. (2006). Conducting in-depth interviews: A guide for designing and conducting in-depth interviews for evaluation input. Pathfinder International.

Buchan, J. (2002). Global nursing shortages. Are often a symptom of wider health system or societal ailments. BMJ, 324, 751-752. https://doi. org/10.1136/bmj.324.7340.751

Chan, Z. C., Tam, W. S., Lung, M. K., Wong, W. Y., \& Chau, C. W. (2013). A systematic literature review of nurse shortage and the intention to leave. Journal of Nursing Management, 21(4), 605-613. https://doi.org/10. 1111/j.1365-2834.2012.01437.x

Cooley, S. S., \& De Gagne, J. C. (2016). Transformative experience: Developing competence in novice nursing faculty. Journal of Nursing Education, 55(2), 96-100. https://doi.org/10.3928/01484834-20160114-07

Deterding, N. M. \& Waters, M. C. (2018). Flexible coding of in-depth interviews: A twenty-first-century approach. Sociological Methods $\mathcal{E}$ Research, 50(2), 708-739. https://doi.org/10.1177/0049124118799377

Dietrich Leurer, M. D., Donnelly, G., \& Domm, E. (2007). Nurse retention strategies: Advice from experienced registered nurses. Journal of Health Organization and Management, 21(3), 307-319. https://doi.org/ 10.1108/14777260710751762

Drobne, S., \& Bogataj, M. (2013). Evaluating functional regions for servicing the elderly. In L. Zadnik Stirn, J. Žerovnik, J. Povh, S. Drobne and A. Lisec (Eds.), The 12th International Symposium on Operational Research SOR'13, Proceedings (pp. 331-336). SDI-SOR.

Drobne, S., \& Bogataj, M. (2014). Regions for servicing old people: Case study of Slovenia. Business Systems Research Journal, 5(3), 19-36. https://doi.org/10.2478/bsrj-2014-0017

Drobne, S., \& Bogataj, M. (2015). Optimal allocation of public service centres in the central places of functional regions. IFAC-PapersOnLine, 48(3), 2362-2367. https://doi.org/10.1016/j.ifacol.2015.06.441

Drobne, S., \& Bogataj, M. (2017). The impact of public investments in facilities on the potential housing market for older persons. Facilities, 35(7/8), 422-435. https://doi.org/10.1108/F-09-2016-0091

Dyrbye, L. N., \& Shanafelt, T. D. (2011). Physician burnout: A potential threat to successful health care reform. Jama, 305(19), 2009-2010. https://doi.org/10.1001/jama.2011.652

European Commission (2015). Innovation for active $\mathcal{E}$ healthy ageing. European Summit on Innovation for Active and Healthy Ageing, Final Report. European Commission and Partners.

Evans, J., \& Frank, B. (2003). Contradictions and tensions: Exploring relations of masculinities in the numerically female-dominated nursing profession. The Journal of Men's Studies, 11(3), 277-292. https://doi. org/10.3149/jms.1103.277

Govindarajan, V., \& Ramamurti, R. (2013). Delivering world-class health care, affordably. Harvard Business Review, 91(11), 117-122.

Haddad, L. M., \& Toney-Butler, T. J. (2018). Nursing shortage. StatPearls Publishing.

Hassmiller, S. B., \& Cozine, M. (2006). Addressing the nurse shortage to improve the quality of patient care. Health Affairs, 25(1), 268-274. https://doi.org/10.1377/hlthaff.25.1.268 
DRUŠ. ISTRAŽ. ZAGREB GOD. 30 (2021), BR. 2, STR. 379-400

GRAH, B. ET AL.: SUSTAINABILITY OF...
Health Workforce Australia (2014). Nursing workforce sustainability, improving nurse retention and productivity. Health Workforce Australia.

Huddleston, P., \& Gray, J. (2016). Measuring nurse leaders' and direct care nurses' perceptions of a healthy work environment in an acute care setting, part 1: A pilot study. JONA: The Journal of Nursing Administration, 46(7/8), 373-378. https://doi.org/10.1097/NNA.000000 0000000361

Janež, P., Drobne, S., \& Bogataj, M. (2018). Forecasting dynamics of daily commuting to work to other municipality in the case of changing taxation policies. In E. Viles, M. Ormazábal, \& A. Lleó (Eds.), Closing the gap between practice and research in industrial engineering (pp. 105-112). Springer. https://doi.org/10.1007/978-3-319-58409-6_12

Kaelin, L. (2011). Care drain: The political making of health worker migration. Journal of Public Health Policy, 32, 489-498. https://doi.org/ 10.1057/jphp.2011.43

Kennedy, D. M. (2017). Creating an excellent patient experience through service education: Content and methods for engaging and motivating front-line staff. Journal of Patient Experience, 4(4), 156-161. https://doi.org/10.1177/2374373517718351

Kieft, R. A., de Brouwer, B. B., Francke, A. L., \& Delnoij, D. M. (2014). How nurses and their work environment affect patient experiences of the quality of care: A qualitative study. BMC Health Services Research, 14(1), 249. https://doi.org/10.1186/1472-6963-14-249

Krug, E., \& Cieza, A. (2019). Strengthening health systems to provide rehabilitation services. Neuropsychological Rehabilitation, 29(5), 672-674. https://doi.org/10.1080/09602011.2017.1319391

Kuokkanen, L., Leino-Kilpi, H., Numminen, O., Isoaho, H., Flinkman, M., \& Meretoja, R. (2016). Newly graduated nurses' empowerment regarding professional competence and other work-related factors. BMC Nursing, 15(1), 22. https://doi.org/10.1186/s12912-016-0143-9

Lay, V. (2007). Sustainable development and leadership. Društvena istraživanja, 16(6), 1031-1053.

Leung, P. P., Wu, C. H., Kwong, C. K., \& Ching, W. K. (2020). Nursing shortage in the public healthcare system: An exploratory study of Hong Kong. Enterprise Information Systems, 14(7), 913-931.

Manton, K. G., Gu, X., \& Lamb, V. L. (2006). Change in chronic disability from 1982 to 2004/2005 as measured by long-term changes in function and health in the US elderly population. Proceedings of the National Academy of Sciences, 103(48), 18374-18379. https://doi.org/10. 1073/pnas.0608483103

Marć, M., Bartosiewicz, A., Burzyńska, J., Chmiel, Z., \& Januszewicz, P. (2019). A nursing shortage - a prospect of global and local policies. International Nursing Review, 66(1), 9-16. https://doi.org/10.1111/inr.12473

Ministry of Education, Science and Sport (n.a.). Podatki z analizo za srednje šole in dijaške domove [Data with analysis for secondary schools and student boarding homes]. Ministry of Education, Science and Sport.

Nardi, D. A. \& Gyurko, C. C. (2013). The global nursing faculty shortage: Status and solutions for change. Journal of Nursing Scholarship, 45(3), 317-326. https://doi.org/10.1111/jnu.12030 
DRUŠ. ISTRAŽ. ZAGREB GOD. 30 (2021), BR. 2, STR. 379-400

GRAH, B. ET AL. SUSTAINABILITY OF...
National Institute for Public Health (n.a.). Zaposleni po poklicnih skupinah in statističnih regijah, Slovenija, letno [Employees by occupational groups and statistical regions, Slovenia, annually]. National Institute for Public Health. https://podatki.nijz.si

Needleman, J., Buerhaus, P. I., Stewart, M., Zelevinsky, K., \& Mattke, S. (2006). Nurse staffing in hospitals: Is there a business case for quality? Health Affairs, 25(1), 204-211. https://doi.org/10.1377/hlthaff.25.1.204

Newman, K., Maylor, U., \& Chansarkar, B. (2001). The nurse retention, quality of care and patient satisfaction chain. International Journal of Health Care Quality Assurance, 14(2), 57-68. https://doi.org/10.1108/095 26860110386500

Nursing Solutions, Inc. (2016). 2016 National healthcare retention $\mathcal{E} R N$ staffing report. Nursing Solutions, Inc.

Pillay, R. (2009). Retention strategies for professional nurses in South Africa. Leadership in Health Services, 22(1), 39-57. https://doi.org/10.1108/ 17511870910928010

Ritter, D. (2011). The relationship between healthy work environments and retention of nurses in a hospital setting. Journal of Nursing Management, 19(1), 27-32. https://doi.org/10.1111/j.1365-2834.2010.01183.x

Roulston, K. (2010). Considering quality in qualitative interviewing. Qualitative Research, 10(2), 199-228. https://doi.org/10.1177/146879410 9356739

Sawaengdee, K., Tangcharoensathien, V., Theerawit, T., Thungjaroenkul, P., Thinkhamrop, W., Prathumkam, P., Chaichaya, N., Thinkhamrop, K., Tawarungruang, C., \& Thinkhamrop, B. (2016). Thai nurse cohort study: Cohort profiles and key findings. BMC Nursing, 15(1), 10. https://doi.org/10.1186/s12912-016-0131-0

Slovenian Statistical Office (n.a.). Delovno aktivno prebivalstvo po: spol, skd dejavnost, leto, starostni razred [Employed population by: sex, skd (Standard Classification of Activities), year, age class]. Slovenian Statistical Office. https://pxweb.stat.si/pxweb/Dialog/SaveShow.asp

Squires, A., Jylhä, V., Jun, J., Ensio, A., \& Kinnunen, J. (2017). A scoping review of nursing workforce planning and forecasting research. Journal of Nursing Management, 25(8), 587-596. https://doi.org/10. 1111/jonm. 12510

Tadić Vujčić, M. (2019). Personal resources and work engagement: A two-wave study on the role of job resources crafting among nurses. Društvena istraživanja, 28(1), 5-24. https://doi.org/10.5559/di.28.1.01

Tur-Porcar, A. M., Cuartero-Monteagudo, N., \& Fernández-Garrido, J. (2019). Learning environments in health and medical studies: The mediating role of emotional intelligence. Sustainability, 11(15), 4011. https://doi.org/10.3390/su11154011

Webber, J. (2011). Nurses must influence governments and policy. International Nursing Review, 58(2), 145-146. https://doi.org/10.1111/j. 1466-7657.2011.00908.x

Yin, R. K. (2011). Qualitative research from start to finish. Guilford Publications. 
DRUŠ. ISTRAŽ. ZAGREB GOD. 30 (2021), BR. 2, STR. $379-400$

GRAH, B. ET AL.: SUSTAINABILITY OF...
Ziolo, M., Filipiak, B. Z., Bąk, I., Cheba, K., Tîrca, D. M., \& Novo-Corti, I. (2019). Finance, sustainability and negative externalities. An overview of the European context. Sustainability, 11(15), 4249. https://doi.org/ $10.3390 /$ su11154249

Zydziunaite, V., Lepaite, D., Åstedt-Kurki, P., \& Suominen, T. (2015). Head nurses' decision-making when managing ethical dilemmas. Baltic Journal of Management, 10(2), 166-187. https://doi.org/10.1108/BJM-122013-0194

\section{Održivost zdravstvenih sustava: modeliranje dinamike zapošljavanja medicinskih sestara s obzirom na starenje stanovništva}

Barbara GRAH, Vlado DIMOVSKI, Sandra PENGER, Simon COLNAR, David BOGATAJ

Ekonomski fakultet, Sveučilište u Ljubljani, Ljubljana, Slovenija

Ova studija želi razviti aktuarski model radi utvrđivanja kvalitetne zdravstvene politike, potrebne kako bi se osigurala održivost zdravstvenoga sustava u smislu definiranja broja kvalificiranih medicinskih sestara koje će, s obzirom na starenje stanovništva i globalnu pandemiju, moći udovoljiti povećanoi potražnji zdravstvenih usluga sve većega broja osoba starije životne dobi. Primijenili smo aktuarsko-matematičku metodu, što je rezultiralo predloženim modelom višestruke redukcije. Model simulira broj raspoloživih radnika uz poznatu dinamiku u sustavu sestrinstva te omogućuje mjerenje kvalitete određenoga nacionalnog zdravstvenog sustava. Numerički primier izrađen je na temelju odabrane članice EU-a primjenom predloženog modela na dostupnim statističkim podacima i 15 intervjua s medicinskim sestrama, obrađenih analizom sadržaja. Uočen je trenutačni manjak broja medicinskih sestara, koji će se nastaviti i u budućnosti. Na nacionalnim je politikama da se to stanje poboliša temeljem primjene predloženog modela višestruke redukcije.

Ključne riječi: održivost zdravstvenoga sustava, stanovništvo starije životne dobi, starenje, zdravstvena zaštita, fluktuacija radne snage, model višestruke redukcije

\section{(c) (i) (5)}

Međunarodna licenca / International License:

Imenovanje-Nekomercijalno / Attribution-NonCommercial 